\title{
Risk Analysis of Consumer Goods Industry Shares on the Indonesia Stock Exchange
}

\section{Rahma Sari Harahap}

Department of Manajemen, Fakultas Ekonomi, Universitas Sumatera Utara, Jl. Dr. T. Mansur No. 9, Sumatera Utara 20222, Indonesia.

E-mail: sariharahap@gmail.com

ARTICLE INFO ABSTRACT

Article history:

Received: 11 March 2021

Revised: 23 Jul 2021

Accepted: 30 Jul 2021

Keywords:

Risk and Return;

Systematic Risk;

Unsystematic Risk;

Single Index Model.

\begin{abstract}
In investation, an investor will face two elements related to the capitals or funds which were invested such as return and risk. Both of these elements have a positive correlation. Basically, the greater the returns obtained, the greater the risks it have, indeed the smaller the returns obtained, the smaller the risks it have. The purposes of this study were to find out and to analyze any differences of systematic risks and unsystematic risks of Food and Beverages subsector, Tobacco Manufacturers subsector, Pharmaceuticals subsector, Cosmetics and Household subsector, and Houseware subsector in Consumer Goods Industry sector that were listed in Indonesia Stock Exchange. The study methods used for this study were data analysis and descriptive analysis. The datas used for this study were secondary data such as 34 Consumer Goods Industry sector companies' stock price in Indonesia Stock Exchange and Jakarta Composite Index from 2012 January 1st until 2012 December 31 st. The hypothesis testing was done by using One Way ANOVA test and Independent Samples t-test with a significance level of 5\%. One Way ANOVA test result shows that there were no systematic risk differences among Food and Beverages subsector, Tobacco Manufacturers subsector, Pharmaceuticals subsector, Cosmetics and Household subsector, and Houseware subsector in Consumer Goods Industry sector that were listed in Indonesia Stock Exchange. The other One Way ANOVA test shows that there were differences among Food and Beverages subsector, Tobacco Manufacturers subsector, Pharmaceuticals subsector, Cosmetics and Household subsector, and Houseware subsector in Consumer Goods Industry sector that were listed in Indonesia Stock Exchange. These differences then were seen in Post Hoc test and Independent Samples t-test. It has been seen that Food and Beverages subsector has a greater unsystematic risk from those of Tobacco Manufacturers subsector and Cosmetics and Household subsector, and then Houseware subsector has a greater unsystematic risk from those of Cosmetics and Household Subsector.
\end{abstract}

Copyright () 2021 Journal of Management Science (JMAS). All rights reserved.

\section{Introduction}

The principle in investing is "high risk high return" which illustrates that there is no investment that does not know risk(West, 2012). Investments in the form of shares are also inseparable from the relatively high risk. Investors' considerations in making the decision to invest or not, include an assessment of how much profit is expected and how far is the investor's tolerance for risk or deviation from the expected results (Aldridge, 2013)(Kiriro, 2013). Two elements attached to every invested capital or fund are return and risk. These two elements have a positive correlation, generally the greater the results obtained, the greater the risk it has, conversely the smaller the results obtained, the smaller the risks faced(Sadka, 2010). In the world of capital markets, risk is divided into two, namely systematic risk and unsystematic risk. The two risks have different characteristics and treatments(H. Erasmus et al., 2012)(H. Erasmus et al., 2012). According to Halim (2005:43) systematic risk is a risk that cannot be eliminated by diversifying, because fluctuations in this risk are influenced by macro factors that can affect the market as a whole(Chawana, 2011)(Mwahunga, 2013). For example inflation, changes in interest rates, foreign exchange rates, government policies, and so on. This risk 
Journal of Management Science (JMAS)

Volume 4. No. 3 July 2021, pp 64-75

e-ISSN: 2684-9747

https://iocscience.org/ejournal/index.php/JMAS

is general in nature and applies to all shares in the relevant stock exchange (Aduda et al., 2012). This risk is also called undiversified risk. Due to its non-diversified nature, this type of risk is calculated through the beta concept. The two risks have different characteristics and treatments (Hibbeln, 2010).

Unsystematic risk is a risk that can be eliminated by diversifying, because this risk only exists in one particular company or industry(H. P. Erasmus, 2011) (H. Erasmus et al., 2012). The magnitude of this risk fluctuation varies from one stock to another because of that difference, each stock has a different level of sensitivity to any market changes(Aloui et al., 2012). For example factors of capital structure, asset structure, level of liquidity, level of profit, and so on. This risk is also called diversified risk (Halim, 2005:44). The consumer goods industry has a very important role in the effort to improve people's lives, where the products are indispensable for daily needs(Weidner et al., 2010). So far, the growth of the consumption sector is a sector that supports economic growth because this sector is growing quite rapidly even when the monetary crisis occurs. This sector is one of the saviors of the national economy. The advantage of the consumer goods industry is the level of inelastic demand, in other words, consumer goods for basic needs are still needed by the community, even though the price increases(Snyder, 2009). The consumer goods industry sub-sectors are the Food and Beverages sub-sector, the Tobacco Manufacturers sub-sector, the Pharmaceuticals sub-sector, the Cosmetics and Household sub-sector, and the Houseware sub-sector(Purbaningsih, 2013)(McClell et al., 2009). The Food and Beverages sub-sector is the food and beverage industry. Currently, there are 14 million business actors in the food and beverage sector. The total turnover of this product in 2012 is predicted to reach Rp700 trillion. The growth of the food and beverage industry in 2012 only grew by $3 \%$. This growth slowed compared to the growth in the same period last year of $4 \%$. The risk of this industry is that the competitiveness of the food and beverage industry is still below other countries such as Thailand, Malaysia, and Brunei Darussalam due to long distribution factors, rising product prices, and weak competitiveness making the domestic food and beverage industry experience a trade deficit (Zulfi, 2010). 2012).

The Tobacco Manufacturers sub-sector is the cigarette industry. In 2012 the government raised the excise rate on tobacco products to an average of $12.2 \%$ with a national cigarette production limit target of 268.4 billion per year. The Ministry of Industry targets the cigarette industry to contribute Rp72 trillion in foreign exchange in 2012. This target can be achieved because the cigarette industry is currently growing rapidly and has become one of the main priorities for the development of the national industry. The Ministry of Industry is currently encouraging the growth of the cigarette industry which has proven to have contributed greatly to industrial growth during 2011. Some of the risks that occur in the cigarette industry are the increasingly strong antismoking movement, reduced support for production programs, increased restrictions on smoking free spaces,

Pharmaceuticals sub-sector is the pharmaceutical industry. The national pharmaceutical industry market in 2012 is estimated to reach around US\$ 4.9 billion or equivalent to Rp 44.6 trillion (Rp 9,100/US\$). This number has increased by about 7\% compared to 2011 which amounted to US\$ 4.57 billion. The national drug raw material market is about $25 \%$ of the total national pharmaceutical market. Currently, it is difficult for Indonesia to develop an industry of raw materials for medicine because the prices of locally made products are not able to compete with imported products, which are much cheaper. "Our raw materials are inefficient and expensive". The import value of medicinal raw materials is predicted to reach $\mathrm{Rp} 11.4$ trillion in 2012, an 8.5\% increase compared to 2011's Rp 9.59 trillion. This figure reaches $95 \%$ of the total medicinal raw materials in Indonesia. The import value of these raw materials has now reached $25 \%$ of the total national pharmaceutical market. This industry is still less attractive to entrepreneurs because it is capital intensive while the business development process is relatively long (DuniaIndustri, 2012).

The Cosmetics and Household sub-sector is the cosmetics and household goods industry. The market opportunity for cosmetic products in Indonesia is very large, so many foreign cosmetic products are targeting the domestic market because the European market has been affected by the crisis(Perakis, 2009)(Bass, 2011). Producers of the national cosmetic industry set a turnover of Rp 11.2 trillion. This amount is up about 15 percent from the current turnover which can reach Rp9.76 trillion. The beauty industry in the next few years will still be a promising sector to cultivate. This is because domestic cosmetic products are not only liked by women, nowadays men also like to buy cosmetic and skin care products (Winarso, 2012).

The Houseware sub-sector is the household appliances industry. Indonesian housewives who are known to be consumptive and like to shop provide a great opportunity for the development of the household goods industry in Indonesia. There are several business risks in the household appliances industry, namely fluctuating world oil prices which greatly affect the cost of production of household appliances, the weakening of the Rupiah against the USD is still a threat to the weakening of the Rupiah against the USD even though in the past year it has become narrower and less volatile.

The relatively stable impact of the Indonesian economy had a positive influence on the movement of 
the JCI in 2012. This can be seen from the increase in foreign investors trading stocks in Indonesia as well as the increase in the sectoral index of a number of sectors. Figure 1.1 shows that the Basic Industry stock index during 2012 rose 28.97 percent, the Miscellaneous Industry stock index 1.94 percent, the Consumer Goods stock index 18.99 percent, the Construction, Property and Real Estate stock index 42.44 percent, the stock index Infrastructure and Utility 29.75 percent, Finance stock index 11.86 percent, Trade \& Service stock index 27.27 percent, and Manufacturing stock index rose 15.66 percent. In addition, there are two sectors that experienced a decline in the index. Both were the Agriculture stock index which fell 3.87 percent and the Mining stock index fell 26,

The phenomenon that developed in connection with the Consumer Goods Industry companies on the Indonesia Stock Exchange in 2012 showed that an increase in domestic consumption was influenced by the company's fundamental factors through innovation of new products, the decline in commodity prices, both prices for basic materials and raw materials, pushed several shares of the Consumer Goods Industry become one of the stocks that investors are eyeing until the end of 2012(Cavusgil et al., 2012)(Hines, 2012)(Liu \& Ye, 2012).

\section{Method}

The type of research used in this research is quantitative research which aims to test theories, build facts, show relationships between variables, provide statistical descriptions, estimate and predict results(Lee \& Hubona, 2009). The research was conducted on the Indonesia Stock Exchange through the internet with the sites www.idx.co.id and www.bi.go.id as well as other sites that support research. The research time was conducted from November 2011 to December 2012. The operational limitations of this research are (a). The risks referred to in this study are systematic risk and unsystematic risk. (b). The sample companies in this study are the Consumer Goods Industry companies listed on the Indonesia Stock Exchange from January 1, 2012 to December 31, 2012. (c). The population is a complete group of elements, which are usually people, objects, transactions, or events in which we are interested in studying them or becoming the object of research (Kuncoro, 2003: 103). The population that is used as the object of this research is all of the Consumer Goods Industry companies listed on the Indonesia Stock Exchange from January 1, 2012 to December 31, 2012. There are 34 companies in the Consumer Goods Industry sector listed on the IDX. The sample is part of the number and characteristics of the population. The sampling technique used was the saturated sample method. The saturated sample method is a sampling technique when all members of the population are used as samples. Another term for saturated sample is census. or events in which we are interested in learning or becoming the object of research (Kuncoro, 2003:103). The population that is used as the object of this research is all of the Consumer Goods Industry companies listed on the Indonesia Stock Exchange from January 1, 2012 to December 31, 2012. There are 34 companies in the Consumer Goods Industry sector listed on the IDX. The sample is part of the number and characteristics of the population. The sampling technique used was the saturated sample method. The saturated sample method is a sampling technique when all members of the population are used as samples. Another term for saturated sample is census. or events in which we are interested in studying it or become the object of research (Kuncoro, 2003: 103). The population that is used as the object of this research is all of the Consumer Goods Industry companies listed on the Indonesia Stock Exchange from January 1, 2012 to December 31, 2012. There are 34 companies in the Consumer Goods Industry sector listed on the IDX. The sample is part of the number and characteristics of the population. The sampling technique used was the saturated sample method. The saturated sample method is a sampling technique when all members of the population are used as samples. Another term for saturated sample is census. The population that is used as the object of this research is all of the Consumer Goods Industry companies listed on the Indonesia Stock Exchange from January 1, 2012 to December 31, 2012. There are 34 companies in the Consumer Goods Industry sector listed on the IDX. The sample is part of the number and characteristics of the population. The sampling technique used was the saturated sample method. The saturated sample method is a sampling technique when all members of the population are used as samples. Another term for saturated sample is census. The population that is used as the object of this research is all of the Consumer Goods Industry companies listed on the Indonesia Stock Exchange from January 1, 2012 to December 31, 2012. There are 34 companies in the Consumer Goods Industry sector listed on the IDX. The sample is part of the number and characteristics of the population. The sampling technique used was the saturated sample method. The saturated sample method is a sampling technique when all members of the population are used as samples. Another term for saturated sample is census. The saturated sample method is a sampling technique when all members of the population are used as samples. Another term for saturated sample is census. The saturated sample method is 
a sampling technique when all members of the population are used as samples. Another term for saturated sample is census.

The type of data used in this study is quantitative data sourced from secondary data, namely data obtained from the publications of the Indonesia Stock Exchange on issuer data, internet media, research journals, reference books, magazines and other newspapers related to the research discussion. .

The method of collecting data in this study is through documentation techniques by collecting supporting data from literature, journals, and reference books to get an overview of the problems studied and collecting relevant secondary data from reports published by the Indonesia Stock Exchange and Bank Indonesia. The data processing method in this study uses SPSS (Statistical Product and Service Solutions) software. Where to input the data previously used Microsoft Excel software.

Data Analysis Techniques using: Descriptive Analysis (Descriptive Analysis, One Way ANOVA Analysis, Analysis of Independent Samples t Test)(ANOVA, 2009)(Bryman \& Cramer, 2012)(Huck, 2012)(Verma, 2012)

\section{Results and Discussion}

Data analysis aims to organize data in a meaningful way so that it can be understood.

Table 1. Data analysis

\begin{tabular}{|c|c|c|c|c|c|c|c|}
\hline \multirow[t]{2}{*}{ Subsektor } & \multirow[t]{2}{*}{ NO } & \multirow[t]{2}{*}{ Code } & \multirow[t]{2}{*}{ Ri } & \multirow[t]{2}{*}{$\mathbf{R m}$} & 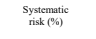 & 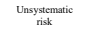 & \multirow{2}{*}{$\begin{array}{l}\text { Total risk } \\
\mathbf{( \% )} \\
\end{array}$} \\
\hline & & & & & $\left(\beta_{i}^{2}\right)\left(\sigma_{m}^{2}\right)$ & $(\%) \sigma_{e i}^{2}$ & \\
\hline \multirow{8}{*}{$\begin{array}{l}\text { Food And } \\
\text { Beverages }\end{array}$} & 1 & ADES & 0,7733 & 0,1308 & 1,18252 & 76,07576 & 77,25827 \\
\hline & 2 & AISA & 0,8959 & 0,1308 & 3,30271 & 86,14903 & 89,45174 \\
\hline & 3 & CEKA & 0,5571 & 0,1308 & 2,92395 & 52,70542 & 55,62937 \\
\hline & 4 & DEVO & 0,0008 & 0,1308 & 0,00018 & 0,07982 & 0,08000 \\
\hline & 5 & DLTA & 0,8509 & 0,1308 & 0,00340 & 85,08949 & 85,09289 \\
\hline & 6 & ICBP & 0,4910 & 0,1308 & 0,82290 & 48,23925 & 49,06214 \\
\hline & 7 & INDF & 0,2683 & 0,1308 & 1,27434 & 25,53008 & 26,80441 \\
\hline & 8 & MLBI & 0,7376 & 0,1308 & 0,00008 & 73,75951 & 73,75959 \\
\hline \multirow{6}{*}{$\begin{array}{l}\text { Food And } \\
\text { Beverages }\end{array}$} & 9 & MYOR & 0,3837 & 0,1308 & 0,42283 & 37,92594 & 38,34877 \\
\hline & 10 & PSDN & 0,1605 & 0,1308 & 0,18943 & 15,86640 & 16,05582 \\
\hline & 11 & ROTI & 0,7850 & 0,1308 & 0,45609 & 77,99827 & 78,45436 \\
\hline & 12 & SKLT & 0,2642 & 0,1308 & 0,00793 & 26,40997 & 26,41790 \\
\hline & 13 & STTP & 0,7877 & 0,1308 & 2,76386 & 75,89498 & 78,65884 \\
\hline & 14 & ULTJ & 0,3152 & 0,1308 & 0,15124 & 31,35828 & 31,50952 \\
\hline \multirow{3}{*}{$\begin{array}{c}\text { Tobacco } \\
\text { Manufacturers }\end{array}$} & 15 & GGRM & $-0,0565$ & 0,1308 & 1,56458 & $-7,20866$ & $-5,64407$ \\
\hline & 16 & HMSP & 0,4283 & 0,1308 & 0,21250 & 42,60058 & 42,81308 \\
\hline & 17 & RMBA & $-0,2322$ & 0,1308 & 0,62046 & $-23,82519$ & $-23,20473$ \\
\hline \multirow{10}{*}{$\begin{array}{c}\text { Pharmaceutica } \\
\text { ls }\end{array}$} & 18 & DVLA & 0,4207 & 0,1308 & 0,20247 & 41,85130 & 42,0 \\
\hline & 19 & INAF & 0,8072 & 0,1308 & 3,02513 & 77,57571 & 80,60085 \\
\hline & 20 & KAEF & 0,9204 & 0,1308 & 4,28475 & 87,59363 & 91,87837 \\
\hline & 21 & KLBF & $-0,3613$ & 0,1308 & 1,86786 & $-37,95660$ & $-36,08875$ \\
\hline & 22 & MERK & 0,1464 & 0,1308 & 0,00003 & 14,64000 & 14,64003 \\
\hline & 23 & PYFA & 0,0696 & 0,1308 & 1,45645 & 5,49648 & 6,95293 \\
\hline & 24 & SCPI & 0,3465 & 0,1308 & 0,00619 & 34,64589 & 34,65208 \\
\hline & 25 & SQBB & 0,0000 & 0,1308 & 0,00000 & 0,00000 & 0,00000 \\
\hline & 26 & SQBI & 0,6969 & 0,1308 & 0,17722 & 69,53658 & 69,71380 \\
\hline & 27 & TSPC & 0,4074 & 0,1308 & 0,47798 & 40,23806 & 40,71604 \\
\hline \multirow{4}{*}{$\begin{array}{c}\text { Cosmetics And } \\
\text { Household }\end{array}$} & 28 & MRAT & 0,0648 & 0,1308 & 1,05045 & 5,42395 & 6,47441 \\
\hline & 29 & MBTO & $-0,0448$ & 0,1308 & 0,22499 & $-4,70321$ & $-4,47822$ \\
\hline & 30 & TCID & 0,3920 & 0,1308 & 0,11614 & 39,07237 & 39,18850 \\
\hline & 31 & UNVR & 0,1820 & 0,1308 & 1,61540 & 16,56509 & 18,18049 \\
\hline \multirow{3}{*}{ Houseware } & 32 & KDSI & 0,9305 & 0,1308 & 0,26204 & 92,74640 & 93,00844 \\
\hline & 33 & KICl & 0,7825 & 0,1308 & 0,17764 & 78,04356 & 78,22120 \\
\hline & 34 & LMPI & 0,4276 & 0,1308 & 1,06746 & 41,65508 & 42,72254 \\
\hline
\end{tabular}

Source: Data processed

\section{Food And Beverages . Subsector}

In Table 1, the results of data analysis on the Food And Beverages sub-sector show that the results of the calculation of the largest individual stock returns (Ri) are found in AISA shares, which are 0.8959, while the smallest individual stock returns (Ri) are in DEVO stocks at 0.0008 . The measurement of market returns gives the value of the return of 0.1308 . The largest systematic risk is in AISA shares of $3.30271 \%$ and the smallest systematic risk is in MLBI shares, which is $0.00008 \%$. The largest unsystematic risk is found in AISA shares, which is $86.14903 \%$ and the smallest unsystematic risk is in DEVO shares, which is $-0.07982 \%$. The largest total risk is in AISA shares of $89.45174 \%$ while the smallest total risk is in DEVO shares of $-0.08000 \%$. Tobacco Manufacturers Sub Subsector

In Table 1, the results of data analysis on the Tobacco Manufacturers sub-sector show that the largest individual stock return (Ri) is in HMSP stock, which is 0.4283 , while the smallest individual stock return (Ri) 
is in RMBA stock of -0.2322 . The measurement of market returns gives the value of the return of 0.1308 . The biggest systematic risk is in GGRM stock of $1.56458 \%$ and the smallest systematic risk is in HMSP stock, which is $0.21250 \%$. The biggest unsystematic risk is in HMSP's stock, which is $42.60058 \%$. The smallest unsystematic risk is found in RMBA shares of $-23,82519 \%$. The largest total risk is in HMSP shares of $42.81308 \%$ while the smallest total risk is in RMBA shares of $-23.20473 \%$.

Pharmaceuticals . Subsector

In Table 1, the results of data analysis on the Pharmaceuticals sub-sector show that the largest individual stock return (Ri) is found in KAEF shares, which is 0.9204 while the smallest individual stock return (Ri) is in KLBF shares of -0.3613 . The measurement of market returns gives the value of the return of 0.1308 . The largest systematic risk is in KAEF shares of $4.28475 \%$ and the smallest systematic risk is in SQBB shares, which is $0.00000 \%$. The biggest unsystematic risk is in KAEF shares, which is $87.59363 \%$. The smallest unsystematic risk is found in KLBF shares of $-37.95660 \%$. The largest total risk is in KAEF shares of 91.87837\% while the smallest total risk is in KLBF shares of $-36.08875 \%$.

\section{Cosmetics And Household Subsector}

In Table 1, the results of data analysis on the Cosmetics And Household sub-sector show that the largest individual stock return (Ri) is found in TCID shares of 0.3920 while the smallest individual stock return (Ri) is found in MBTO shares of -0.0448 . The measurement of market returns gives the value of the return of 0.1308 . The biggest systematic risk is in UNVR stock at $1.61540 \%$ and the smallest systematic risk is in TCID stock at $0.11614 \%$. The biggest unsystematic risk is in TCID shares, which is $39.07237 \%$. The smallest unsystematic risk is found in MBTO shares of $-4.70321 \%$. The largest total risk is in TCID shares of $39.18850 \%$ while the smallest total risk is in MBTO shares of -4.47822 .

\section{Houseware Subsector}

In Table 1, the results of data analysis on the Houseware sub-sector show that the largest individual stock return ( $\mathrm{Ri})$ is found in KDSI shares, which is 0.9305 while the smallest individual stock returns (Ri) is in LMPI shares at 0.4276 . The measurement of market returns gives the value of the return of 0.1308 . The largest systematic risk is found in LMPI shares of $1.06746 \%$ and the smallest systematic risk is found in KICI shares, which is $0.17764 \%$. The biggest unsystematic risk is in KDSI shares, which is $92.74640 \%$. The smallest unsystematic risk is found in LMPI shares of $41.65508 \%$. The largest total risk is in KDSI shares of $93.00844 \%$ while the smallest total risk is in LMPI shares of 42.72254.

\section{Descriptive Analysis}

Descriptive analysis is an analytical method in which the data collected and classified or grouped are then analyzed and interpreted objectively. The results of the estimation of the variables in this study are as follows:

\section{Systematic Risk Description Analysis.}

Table 2. Systematic Risk Descriptive Analysis

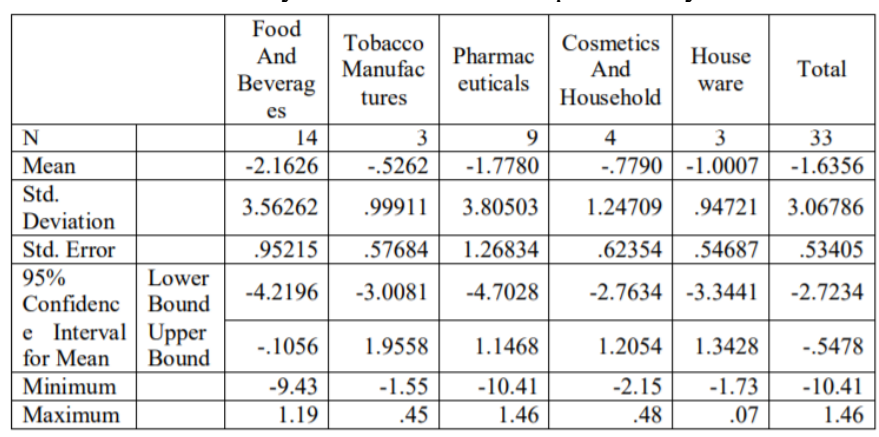

Table 2 shows that the largest and smallest systematic risk is in the Pharmaceuticals sub-sector. The largest systematic risk is 1.46 and the smallest systematic risk is -10.41 with an average of -1.7780 and a standard deviation of 3.80503. This shows that the systematic risk of the Consumer Goods Industry sub-sector is very small, which means that the company's external conditions are in a stable condition so that it is very supportive of the investment climate. 


\section{Journal of Management Science (JMAS)}

Volume 4. No. 3 July 2021, pp 64-75

e-ISSN: 2684-9747

https://iocscience.org/ejournal/index.php/JMAS

\section{Unsystematic Risk Description Analysis.}

Table 3. Unsystematic Risk Descriptive Analysis

\begin{tabular}{|c|c|c|c|c|c|c|c|}
\hline & & $\begin{array}{c}\text { Food } \\
\text { And } \\
\text { Bevera } \\
\text { ges }\end{array}$ & $\begin{array}{c}\text { Tobacco } \\
\text { Manufac } \\
\text { tures }\end{array}$ & $\begin{array}{l}\text { Pharmac } \\
\text { euticals }\end{array}$ & \begin{tabular}{|c|} 
Cosmet \\
ics And \\
Househ \\
old
\end{tabular} & $\begin{array}{c}\text { House } \\
\text { ware }\end{array}$ & Total \\
\hline $\mathrm{N}$ & & 14 & 3 & 10 & 4 & 3 & 34 \\
\hline Mean & & 50.934 & 3.855 & 33.362 & 14.089 & 7.081 & 3.903 \\
\hline $\begin{array}{l}\text { Std. } \\
\text { Deviation }\end{array}$ & & 2.847 & 3.456 & 3.894 & 1.878 & 2.630 & 3.505 \\
\hline Std. Errc & & 7.61 & 1.9957 & 31 & 9.392 & 1.518 & 6.012 \\
\hline $95 \%$ & . & 34.493 & & .501 & -15.800 & 5.478 & 2.679 \\
\hline $\begin{array}{l}\text { Confidence } \\
\text { Interval for } \\
\text { Mean }\end{array}$ & $\begin{array}{l}\text { Bound } \\
\text { Upper } \\
\text { Bound } \\
\end{array}$ & 67.375 & 89.725 & 61.223 & 43.979 & 1.361 & 5.126 \\
\hline Minimum & & .079 & -25.025 & -37.956 & -4.703 & 41.655 & -3.795 \\
\hline Maximum & & 86.149 & 42.600 & 87.593 & 39.072 & 92.746 & 9.274 \\
\hline
\end{tabular}

Table 3 shows that the largest unsystematic risk is in the Houseware subsector, which is 92,746 with an average of 7,081 and a standard deviation of 2,630 and the smallest unsystematic risk is in the Pharmaceuticals subsector of $-37,956$ with an average of 33,362 and a standard deviation of 3,894. This shows that the unsystematic risk of the Consumer Goods Industry sub-sector is very large, which means that the company's internal condition is not in a good condition so that it does not attract investors to invest in the Consumer Goods Industry sub-sector.

\section{One Way ANOVA Analysis}

Prior to the ANOVA test, the variance similarity test (homogeneity) was carried out. Analysis of homogeneity of variance is useful for knowing whether the variance of the data group is the same or homogeneous.

\section{Analysis of the Test of Homogeneity of Variances Systematic Risk}

Table 4. Test Results of the Test of Homogeneity of Variances Systematic Risk

\begin{tabular}{|c|c|c|c|}
\hline Levene Statistic & df1 & df2 & Sig. \\
\hline 1.772 & 4 & 28 & .163 \\
\hline
\end{tabular}

The assumption in the ANOVA test is that the variance of the data groups is the same or homogeneous. The test criteria are, if the significance is $<0.05$, then the variance of the data group is not the same, on the contrary if the significance is $>0.05$, then the variance of the data group is the same. From the output, it can be seen that the significance is $>0.05(0.163>0.05)$. So, it can be concluded that the variance of the five data groups, namely the Food and Beverages Sub-sector, Tobacco Manufacturers Sub-sector, Pharmaceuticals Sub-sector, Cosmetics and Household Sub-sector, and Houseware Sub-sector are the same, so this has fulfilled the basic assumption.

Analysis of Test Of Homogeneity of Variances Unsystematic Risk.

Table 5.Test results of the Test of Homogeneity of Variances Unsystematic Risk.

\begin{tabular}{|c|c|c|c|}
\hline Levene Statistic & $\mathrm{dfl}$ & df2 & Sig. \\
\hline .835 & 4 & 29 & .514 \\
\hline
\end{tabular}

The assumption in the ANOVA test is that the variance of the data groups is the same or homogeneous. The test criteria are, if the significance is $<0.05$, then the variance of the data group is not the same, on the contrary if the significance is $>0.05$, then the variance of the data group is the same. From the output, it can be seen that the significance is $>0.05(0.514>0.05)$. So, it can be concluded that the variance of the five data groups, namely the Food and Beverages Sub-sector, Tobacco Manufacturers Sub-sector, Pharmaceuticals Sub-sector, Cosmetics and Household Sub-sector, and Houseware Sub-sector are the same, so this has fulfilled the basic assumption. The analysis of the ANOVA test was to determine whether there was a difference between systematic risk and unsystematic risk in the Food and Beverages Sub-sector, Tobacco Manufacturers Subsector, Pharmaceuticals Sub-sector, Cosmetics and Household Sub-sector. 


\section{Systematic Risk ANOVA Test Analysis.}

Table 6. Systematic Risk ANOVA Test Results.

\begin{tabular}{|l|c|c|c|c|c|}
\hline & $\begin{array}{c}\text { Sum of } \\
\text { Squares }\end{array}$ & Df & Mean Square & F & Sig. \\
Between Groups & 11.908 & 4 & 2.977 & .288 & .883 \\
\hline Within Groups & 289.268 & 28 & 10.331 & & \\
Total & 301.176 & 32 & & & \\
\hline
\end{tabular}

In Table 6, it can be seen that F count $<F$ table $(0.288<2.714)$ and significant $>0.05(0.883>0.05)$, then Ho is accepted. So, it can be concluded that there is no average difference between systematic risk in the Food and Beverages Subsector, Tobacco Manufacturers Subsector, Pharmaceuticals Subsector, Cosmetics and Household Subsector, and Houseware Subsector.

Unsystematic Risk ANOVA Test Analysis

Table 7. Unsystematic Risk ANOVA Test Results.

\begin{tabular}{|l|c|c|c|c|c|}
\cline { 1 - 2 } & \multicolumn{1}{c|}{$\begin{array}{c}\text { Sum of } \\
\text { Squares }\end{array}$} & Df & Mean Square & F & Sig. \\
Between Groups & 11535.950 & 4 & 2883.988 & 2.882 & .040 \\
\hline Within Groups & 29024.589 & 29 & 1000.848 & & \\
\hline Total & 40560.540 & 33 & & & \\
\hline
\end{tabular}

In Table 7 it can be seen that $\mathrm{F}$ arithmetic $>\mathrm{F}$ table $(2.882>2.701)$ and significant $<0.05(0.040<0.05)$, then Ho is rejected. So, it can be concluded that there is an average difference between unsystematic risk in the Food and Beverages Subsector, Tobacco Manufacturers Subsector, Pharmaceuticals Subsector, Cosmetics and Household Subsector, and Houseware Subsector.

Post Hoc Test Analysis of Unsystematic Risk

Post Hoc Test analysis is used to see differences in unsystematic risk between sub-sectors. This will be proven by the Tukey and Bonferroni test. Whether or not there is a difference in the average difference between the five sub-sectors is determined by the asterisk $\left(^{*}\right)$ in the mean difference column. If there is a sign $(*)$ in the mean difference, then the number is significant, otherwise if there is no sign $(*)$ then the number is not significant. The results of the Multiple Comparison test in the mean difference column with the Tukey and Bonferroni tests show that there is a difference but not significant between the Food And Beverages Sub-sector, Tobacco Manufactures Sub-sector, Pharmaceuticals Sub-sector, Cosmetics And Household Sub-sector, and Houseware Sub-sector.

\section{Homogeneous Analysis of Unsystematic Risk Subsets}

Homogeneous Subsets test analysis is used to see sub-sectors that have an average (not different) significantly similarity.

Table 8. Unsystematic Risk Homogeneous Test Results.

\begin{tabular}{|c|c|c|c|c|}
\hline \multirow{2}{*}{\multicolumn{2}{|c|}{ Subsektor }} & \multirow{2}{*}{$\mathrm{N}$} & \multicolumn{2}{|c|}{ Subset for alpha $=0.05$} \\
\hline & & & 1 & 2 \\
\hline \multirow[t]{6}{*}{$\begin{array}{l}\text { Tukey } \\
\text { HSDa }\end{array}$} & Tobacco Manufactures & 3 & 3.8556 & \\
\hline & Cosmetics And Household & 4 & 1.4089 & 1.4089 \\
\hline & Pharmaceuticals & 10 & 3.3362 & 3.3362 \\
\hline & Food And Beverages & 14 & 5.0934 & 5.0934 \\
\hline & Houseware & 3 & & 7.0815 \\
\hline & Sig. & & .188 & .076 \\
\hline
\end{tabular}

In Table 8, subset 1 shows that the Food And Beverages Subsector, Tobacco Manufactures Subsector, Pharmaceuticals Subsector, Cosmetics And Household Subsector there are no significant differences between one another and between the Food And Beverages Subsector, Tobacco Manufactures Subsector, Pharmaceuticals Subsector, Cosmetics And Household Subsector there is a significant difference with the Houseware Subsector. In subset 2, it can be seen that the Food And Beverages Subsector, Pharmaceuticals Subsector, Cosmetics And Household Subsector, and Houseware Subsector there are no significant differences between one another and between the Food And Beverages Subsector, Tobacco Manufactures Subsector, Pharmaceuticals Subsector, and Cosmetics And Household Subsector there are significant difference with the Tobacco Manufactures Subsector.

\section{Analysis of Independent Samples t Test Unsystematic Risk}

To further clarify the differences between each sub-sector, an Independent sample $t$ test was carried 
out. Independent here in the sense that they are not related, are not related, come from two different populations. The tests are as follows:

Table 9. Independent Samples t Test Results Consumer Goods Industry

\begin{tabular}{|c|c|c|c|c|c|c|}
\hline \multicolumn{2}{|c|}{ Subsektor } & $\begin{array}{l}\text { Food And } \\
\text { Beverages }\end{array}$ & $\begin{array}{c}\text { Tobacco } \\
\text { Manufac } \\
\text { turers }\end{array}$ & $\begin{array}{l}\text { Pharm } \\
\text { aceutic }\end{array}$ & $\begin{array}{c}\text { Cosmetics } \\
\text { And }\end{array}$ & $\begin{array}{c}\text { House } \\
\text { ware }\end{array}$ \\
\hline $\begin{array}{l}\text { Food And } \\
\text { Beverages }\end{array}$ & $\begin{array}{l}\text { F }_{\text {hitung }} \\
\text { Sig } \\
\mathrm{T}_{\text {hitung }} \\
\text { Sig.(2-tailed) } \\
\text { Df }\end{array}$ & - & \begin{tabular}{r|}
0.028 \\
0.870 \\
2.520 \\
0.024 \\
15
\end{tabular} & $\begin{array}{r}0.648 \\
0.429 \\
1.280 \\
0.214 \\
22\end{array}$ & $\begin{array}{r}2.308 \\
0.148 \\
2.414 \\
0.028 \\
16 \\
\end{array}$ & $\begin{array}{r}0.383 \\
0.545 \\
-1.108 \\
0.285 \\
15\end{array}$ \\
\hline $\begin{array}{c}\text { Tobacco } \\
\text { Manufactu } \\
\text { rers }\end{array}$ & $\begin{array}{l}\mathrm{F}_{\text {hitung }} \\
\text { Sig } \\
\mathrm{T}_{\text {hitung }} \\
\text { Sig.(2-tailed) } \\
\text { Df }\end{array}$ & $\begin{array}{r}0.028 \\
0.870 \\
2.520 \\
0.024 \\
15\end{array}$ & - & $\begin{array}{r}0.102 \\
0.756 \\
-1.174 \\
0.265 \\
11\end{array}$ & $\begin{array}{r}1.812 \\
0.236 \\
-0.510 \\
0.632 \\
5\end{array}$ & $\begin{array}{r}0.648 \\
0.429 \\
1.280 \\
0.214 \\
22\end{array}$ \\
\hline $\begin{array}{c}\text { Pharmaceu } \\
\text { ticals }\end{array}$ & $\begin{array}{l}\mathrm{F}_{\text {hitung }} \\
\mathrm{Sig} \\
\mathrm{T}_{\text {hitung }} \\
\text { Sig.(2-tailed) } \\
\text { Df }\end{array}$ & $\begin{array}{r}0.648 \\
0.429 \\
1.280 \\
0.214 \\
22\end{array}$ & $\begin{array}{r}0.102 \\
0.756 \\
-1.174 \\
0.265 \\
11\end{array}$ & - & $\begin{array}{r}1.949 \\
0.188 \\
0.930 \\
0.370 \\
12\end{array}$ & $\begin{array}{r}0.625 \\
0.446 \\
-1.539 \\
0.152 \\
11\end{array}$ \\
\hline $\begin{array}{c}\text { Cosmetics } \\
\text { And } \\
\text { Household }\end{array}$ & $\begin{array}{l}\text { F }_{\text {hitung }} \\
\text { Sig } \\
\mathrm{T}_{\text {hitung }} \\
\text { Sig.(2-tailed) } \\
\text { Df }\end{array}$ & $\begin{array}{r}2.308 \\
0.148 \\
2.414 \\
0.028 \\
16\end{array}$ & $\begin{array}{r}1.812 \\
0.236 \\
-0.510 \\
0.632 \\
5\end{array}$ & $\begin{array}{r}1.949 \\
0.188 \\
0.930 \\
0.370 \\
12\end{array}$ & - & $\begin{array}{r}0.504 \\
0.509 \\
-3.361 \\
0.20 \\
5\end{array}$ \\
\hline Houseware & $\begin{array}{l}\mathrm{F}_{\text {hitung }} \\
\mathrm{Sig} \\
\mathrm{T}_{\text {hitung }} \\
\text { Sig.(2-tailed) } \\
\text { Df }\end{array}$ & $\begin{array}{r}0.383 \\
0.545 \\
-1.108 \\
0.285 \\
15\end{array}$ & \begin{tabular}{r|r|}
0.648 \\
0.429 \\
1.280 \\
0.214 \\
22
\end{tabular} & $\begin{array}{r}0.625 \\
0.446 \\
-1.539 \\
0.152 \\
11\end{array}$ & $\begin{array}{r}0.504 \\
0.509 \\
-3.361 \\
0.20 \\
5\end{array}$ & - \\
\hline
\end{tabular}

Independent Samples t Test Food And Beverages and Tobacco Manufacturers.

In Table 9 it can be seen that the calculated $F$ is 0.028 with a probability of 0.870 . Because the probability is $>0.05$, it can be said that there is no difference in variance in the Food And Beverages and Tobacco Manufacturers sub-sectors. If the two variances are the same, then Equal Variances Assumed is used. Because $t$ count $>t$ table $(2.520>-2.131)$ and significance $<0.05(0.024<0.05)$, then Ho is rejected. So, it can be concluded that there is a difference in the average unsystematic risk between the Food And Beverages and Tobacco Manufacturers sub-sectors. Based on the average unsystematic risk of the Food and Beverages sub-sector of 50.93444\% and the Tobacco Manufacturers sub-sector of $3.85558 \%$ with an average difference of $47,07886 \%$ and based on information $95 \%$ confidence interval of means that the difference in the factors causing unsystematic risk between the two is between 7.2645 to 8.6893. So it can be concluded that the Food and sub-sector has a greater unsystematic risk than the Tobacco Manufacturers sub-sector.

\section{Independent Samples t Test Food And Beverages and Pharmaceuticals.}

In Table 9 it can be seen that the calculated $F$ is 0.648 with a probability of 0.429 . Because the probability is $>0.05$, it can be said that there is no difference in variance in the Food And Beverages and Pharmaceuticals sub-sectors. If the two variances are the same, then Equal Variances Assumed is used. Because $t$ count $>t$ table $(1.280>-2.074)$ and significance $>0.05(0.214>0.05)$, then Ho is accepted. So, it can be concluded that there is no difference in the average unsystematic risk between the Food And Beverages and Pharmaceuticals sub-sectors.

Independent Samples t Test Food And Beverages and Cosmetics And Household.

In Table 9 it can be seen that the calculated $F$ is 2,308 with a probability of 0.148 . Because the probability is $>0.05$, it can be said that there is no difference in variance in the Food And Beverages and Cosmetics And Household sub-sectors. If the two variances are the same, then Equal Variances Assumed is used. Because $t$ count $>t$ table $(2.414>-2.120)$ and significance $<0.05(0.028<0.05)$, then Ho is rejected. So, it can be concluded that there is a difference in the average unsystematic risk between the Food And Beverages and Cosmetics And Household sub-sectors. Based on the average unsystematic risk of the Food and Beverages sub-sector of 50.9344\% and the Cosmetics And Household sub-sector of $14.08955 \%$ with an average difference of 36 between the two sub-sectors. $84489 \%$ and based on information $95 \%$ confidence interval of means that the difference in the factors causing unsystematic risk between the two is between 4.4843 to 6.9205 . So it can be concluded that the Food and Beverages sub-sector has a greater unsystematic risk than the Cosmetics And Household sub-sector.

Independent Samples t Test Food And Beverages and Houseware.

In Table 9 it can be seen that the calculated $F$ is 0.383 with a probability of 0.545 . Because the

71 
probability is $>0.05$, it can be said that there is no difference in variance in the Food And Beverages and Houseware sub-sectors. If the two variances are the same, then Equal Variances Assumed is used. Because $t$ count $>$ t table $(-1.108>-2.131)$ and significance $>0.05(0.285>0.05)$, then Ho is accepted. So, it can be concluded that there is no difference in the average unsystematic risk between the Food And Beverages and Houseware sub-sectors.

Independent Samples t Test Tobacco Manufacturers and Pharmaceuticals.

In Table 9 it can be seen that the calculated $F$ is 0.102 with a probability of 0.756 . Because the probability is $>$ than 0.05 , it can be said that there is no difference in variance in the Tobacco Manufacturers and Pharmaceuticals sub-sectors. If the two variances are the same, then Equal Variances Assumed is used. Because $t$ count $>t$ table $-1.174>-2.201)$ and significance $>0.05(0.265>0.05)$, then Ho is accepted. So, it can be concluded that there is no difference in the average unsystematic risk between the Tobacco Manufacturers and Pharmaceuticals sub-sectors.

Independent Samples t Test Tobacco Manufacturers and Cosmetics And Household.

In Table 9 it can be seen that the calculated $F$ is 1.812 with a probability of 0.236 . Because the probability is $>$ than 0.05 , it can be said that there is no difference in variance in the Tobacco Manufacturers and Cosmetics And Household sub-sectors. If the two variances are the same, then Equal Variances Assumed is used. Because $t$ count $>t$ table $(-0.510>-2.571)$ and significance $>0.05(0.632>0.05)$, then Ho is accepted. So, it can be concluded that there is no difference in the average unsystematic risk between the Tobacco Manufacturers and Cosmetics And Household sub-sectors.

Independent Samples $t$ Test Tobacco Manufacturers and Houseware.

In Table 9 it can be seen that the calculated $F$ is 0.648 with a probability of 0.429 . Because the probability is $>$ than 0.05 , it can be said that there is no difference in variance in the Tobacco Manufacturers and Houseware sub-sectors. If the two variances are the same, then Equal Variances Assumed is used. Because $\mathrm{t}$ count $>\mathrm{t}$ table $(1.280>-2.074)$ and significance $>0.05(0.214>0.05)$, then Ho is accepted. So, it can be concluded that there is no difference in the average unsystematic risk between the Tobacco Manufacturers and Houseware sub-sectors.

Independent Samples t Test Pharmaceuticals and Cosmetics And Household.

In Table 9 it can be seen that the calculated $F$ is 1,949 with a probability of 0.188 . Because the probability is $>0.05$, it can be said that there is no difference in variance in the Pharmaceuticals and Cosmetics And Household sub-sectors. If the two variances are the same, then Equal Variances Assumed is used. Because $\mathrm{t}$ count $>\mathrm{t}$ table $(0.930>-2.179)$ and significance $>0.05(0.370>0.05)$, then Ho is accepted. So, it can be concluded that there is no difference in the average unsystematic risk between the Pharmaceuticals and Cosmetics And Household sub-sectors.

Independent Samples $t$ Test Pharmaceuticals and Houseware.

In Table 9 it can be seen that the calculated $F$ is 0.625 with a probability of 0.446 . Because the probability is $>0.05$, it can be said that there is no difference in variance in the Pharmaceuticals and Houseware sub-sectors. If the two variances are the same, then Equal Variances Assumed is used. Because $t$ count $>t$ table $-1.539>-2.201)$ and significance $>0.05(0.152>0.05)$, then Ho is accepted. So, it can be concluded that there is no difference in the average unsystematic risk between the Pharmaceuticals and Houseware sub-sectors.

Independent Samples t Test Cosmetics And Household and Houseware.

In Table 9 it can be seen that the calculated $F$ is 0.504 with a probability of 0.509 . Because the probability is $>0.05$, it can be said that there is no difference in variance in the Pharmaceuticals and Houseware sub-sectors. If the two variances are the same, then Equal Variances Assumed is used. Because $t$ count $>t$ table $(-3.361>-2.571)$ and significance $<0.05(0.020<0.05)$, then Ho is rejected. So, it can be concluded that there is a difference in the average unsystematic risk between the Cosmetics And Household and Houseware subsectors. Based on the average unsystematic risk of the Cosmetics And Household sub-sector of 14.08955\% and the Houseware sub-sector of $70.81502 \%$ with an average difference of -56 between the two sub-sectors. 72546 and based on information $95 \%$ confidence interval of means that the difference in the factors causing unsystematic risk between the two is between -1.0011 to -1.333 . So it can be concluded that the Cosmetics And Household sub-sector has a greater unsystematic risk than the Houseware sub-sector.

Food and Beverages subsector systematic risk $\left(\mathrm{X}_{1.1}\right)$

The average Beta in the Food and Beverages sub-sector of 0.528 indicates that stocks in the Food and Beverages sub-sector are stocks that survive or are defensive stocks because changes in stock returns are smaller than those in the market, meaning that stocks have less volatile returns. with changes in market returns. Therefore, stocks should be sold to avoid losses (Halim, 31: 2005). The results of the One Way ANOVA test analysis can be concluded that there is no significant difference between the five systematic risks of the sub- 
sectors studied because the five sub-sectors have an average Beta of less than one.

Tobacco Manufacturers subsector systematic risk $\left(\mathrm{X}_{1.2}\right)$

The average Beta in the Tobacco Manufacturers sub-sector of 0.640 indicates that the stocks in the Tobacco Manufacturers sub-sector are stocks that survive or are defensive stocks because changes in stock returns are smaller than those in the market, meaning that stocks have returns that are less volatile with changes market returns. Therefore, stocks should be sold to avoid losses (Halim, 31: 2005).

Pharmaceuticals subsector systematic risk $\left(\mathrm{X}_{1.3}\right)$

The average Beta in the Pharmaceuticals sub-sector of 0.539 indicates that the stocks in the Pharmaceuticals sub-sector are defensive stocks because the change in stock returns is smaller than in the market, meaning that the stock has a less volatile return with changes in market returns. . Therefore, stocks should be sold to avoid losses (Halim, 31: 2005).

\section{Cosmetics and Household subsector systematic risk $\left(\mathbf{X}_{1.4}\right)$}

The average Beta in the Cosmetics and Household sub-sector of 0.597 indicates that the stocks in the Cosmetics and Household sub-sector are stocks that survive or are defensive stocks because changes in stock returns are smaller than those in the market, meaning that stocks have less volatile returns. with changes in market returns. Therefore, stocks should be sold to avoid losses (Halim, 31: 2005).

\section{Houseware subsector systematic risk $\left(\mathbf{X}_{1.5}\right)$}

The average Beta of 0.503 in the Houseware sub-sector indicates that the stocks in the Houseware sub-sector are defensive stocks because the change in stock returns is smaller than what occurs in the market, meaning that the stock has a less volatile return with changes in market returns. . Therefore, stocks should be sold to avoid losses (Halim, 31: 2005).

\section{Food and Beverages subsector unsystematic risk $\left(X_{2.1}\right)$}

The results of the Independent Samples t Test analysis show that the Food and Beverages sub-sector is significantly different from the Tobacco Manufacturers sub-sector where the Food and Beverages sub-sector has a greater unsystematic risk than the Tobacco Manufacturers sub-sector due to the large number of new competitors entering the Food and Beverages sub-sector by offering different products. -different from existing companies, consumers can choose the products they want, for example consumers are bored with traditional foods, these consumers will switch to fast food while the Tobacco Manufacturers sub-sector is a company that remains afloat because the demand for the products produced will remain stable although there is a decline, it does not affect the company's activities in generating optimal profits because the smoking habit of the Indonesian people is classified as intense.The Food and Beverages sub-sector has a greater unsystematic risk than the Cosmetics and Household sub-sector because there are many new competitors entering the Food and Beverages sub-sector by offering different products from existing companies, so consumers can choose the products they want, for example, consumers are bored. With traditional foods, these consumers will switch to fast food, while the Cosmetics and Household sub-sector is an industry where the market opportunity for cosmetic products in Indonesia is growing rapidly, this can be seen from the increase in the use of cosmetic products in the country along with the increase in people's purchasing power. on the increase in the company's stock price.

Unsystematic risk of the Tobacco Manufacturers subsector $\left(\mathbf{X}_{2.2}\right)$

The results of the Independent Samples t Test analysis show that the Tobacco Manufacturers subsector is more at risk than the Cosmetics and Household sub-sector.

\section{Pharmaceuticals subsector unsystematic risk $\left(\mathbf{X}_{2.3}\right)$}

The results of the Independent Samples t Test analysis show that there is no significant difference between the Pharmaceuticals sub-sector and other sub-sectors.

Cosmetics and Household subsector unsystematic risk $\left(X_{2.4}\right)$

The results of the Independent Samples t Test analysis show that there is a significant difference between the Cosmetics and Household sub-sector and the Food and Beverages sub-sector where the Cosmetics and Household sub-sector has a lower unsystematic risk than the Food and Beverages sub-sector.There are differences in the Houseware sub-sector with the Cosmetics and Household sub-sector where the Houseware sub-sector has a greater unsystematic risk than the Cosmetics and Household sub-sector because the Cosmetics and Household sub-sector is an industry where the market opportunity for cosmetic products in Indonesia is growing rapidly, this can be seen from the increase in the use of cosmetic products in Indonesia. In the domestic market, along with the increase in people's purchasing power, it will affect the increase in the company's stock price, while in the Houseware sub-sector the growth of a home industry for household products, especially with low costs and low selling prices makes competition more severe and becomes a challenge for companies to deal with it through quality improvement and the best service. 


\section{Houseware subsector unsystematic risk $\left(\mathbf{X}_{2.5}\right)$}

The results of the Independent Samples t Test analysis show that the Houseware sub-sector is more risky than the Cosmetics and Household sub-sector can be seen in the discussion above.

\section{Conclusion}

Based on the results of the research and discussion that have been stated previously, several conclusions can be drawn as follows: (1). The results of the One Way ANOVA test concluded that there was no significant difference between the systematic risk of the Food and Beverages sub-sector, the Tobacco Manufacturers subsector, the Pharmaceuticals sub-sector, the Cosmetics and Household sub-sector, and the Houseware sub-sector because the five sub-sectors had an average Beta of less than one. (2). The results of the One Way ANOVA test concluded that there were significant differences between the unsystematic risk of the Food and Beverages sub-sector, the Tobacco Manufacturers sub-sector, the Pharmaceuticals sub-sector, the Cosmetics and Household sub-sector, and the Houseware sub-sector. To further clarify the differences between each subsector, the Independent Sample t Test was carried out. The results of the Independent Sample t Test test showed that the Food and Beverages subsector had a greater unsystematic risk than the Tobacco Manufacturers subsector, the Food and Beverages subsector had a greater unsystematic risk than the Cosmetics and Household subsector, and the Houseware subsector had an unsystematic risk. larger systematics than the Cosmetics and Household subsector.

\section{References}

Aduda, J., Odera, E. O., \& Onwonga, M. (2012). The behaviour and financial performance of individual investors in the trading shares of companies listed at the Nairobi stock exchange, Kenya. Journal of Finance and Investment Analysis, 1(3), 33-60.

Aldridge, I. (2013). High-frequency trading: a practical guide to algorithmic strategies and trading systems (Vol. 604). John Wiley \& Sons.

Aloui, C., Nguyen, D. K., \& Njeh, H. (2012). Assessing the impacts of oil price fluctuations on stock returns in emerging markets. Economic Modelling, 29(6), 2686-2695.

ANOVA, O. (2009). One-way ANOVA.

Bass, H. H. (2011). Mali's Agro-Industry: A SWOT-Analysis. A Note about the Cover, 136.

Bryman, A., \& Cramer, D. (2012). Quantitative data analysis with IBM SPSS 17, 18 \& 19: A guide for social scientists. Routledge.

Cavusgil, S. T., Ghauri, P. N., \& Akcal, A. A. (2012). Doing business in emerging markets. Sage.

Chawana, M. (2011). The effect of systematic risk factors on stock returns in a developing country: The case of South Africa. University of Johannesburg.

Erasmus, H. P. (2011). Valuing privately-owned companies in South Africa: adjusting for unsystematic risk. North-West University.

Erasmus, H., van Rooyen, S., \& Oberholzer, M. (2012). Unsystematic risk in South African privately-owned company valuations. Journal of Applied Business Research (JABR), 28(3), 449-462.

Hibbeln, M. (2010). Risk Management in Credit Portfolios: Concentration Risk and Basel II. Springer Science \& Business Media.

Hines, T. (2012). Supply Chain Strategies: Customer Driven and Customer Focused: Demand Driven and Customer Focused. Routledge.

Huck, S. W. (2012). Reading statistics and research. Pearson Education.

Kiriro, D. K. (2013). The relationship between risk and growth in corporate investment for firms listed in the Nairobi Securities Exchange. University of Nairobi.

Lee, A. S., \& Hubona, G. S. (2009). A scientific basis for rigor in information systems research. MIS Quarterly, 237-262.

Liu, Y., \& Ye, H. (2012). The dynamic study on firm's environmental behavior and influencing factors: an adaptive agentbased modeling approach. Journal of Cleaner Production, 37, 278-287.

McClell, T., Genev, V., Fitch, J., Tedrow, T., Russell, T., Martin, A., Gabowski, G., Bauernschmidt, K., Iriarte, L., \& Somji, A. (2009). Crummer/Suntrust Portfolio: Analysis and Recommendations [2009].

Mwahunga, C. F. (2013). ASSESS THE SIGNIFICANCE OF RETURN INTERVAL ON THE ESTIMATION OF SYSTEMATIC RISK IN LISTED COMPANIES TRADING IN THE NAIROBI SECURITIES EXCHANGE. SCHOOL OF BUSINESS, KENYATTA UNIVERSITY.

Perakis, S. M. (2009). Improving the quality of women's gold in Mali, West Africa: The case of Shea.

Purbaningsih, Y. P. (2013). Using Altman Z-Score Model and Current Status Of Financial Ratio to Asses Of Consumer Goods Company Listed in Indonesia Stock Exchange (IDX). International Conference On Law, Business and Governance (ICon-LBG), 1 .

Sadka, R. (2010). Liquidity risk and the cross-section of hedge-fund returns. Journal of Financial Economics, 98(1), 54- 


\section{Journal of Management Science (JMAS)}

Volume 4. No. 3 July 2021, pp 64-75

https://iocscience.org/ejournal/index.php/JMAS

71.

Snyder, J. (2009). What's the matter with price gouging? Business Ethics Quarterly, 19(2), 275-293.

Verma, J. P. (2012). Data analysis in management with SPSS software. Springer Science \& Business Media.

Weidner, K. L., Rosa, J. A., \& Viswanathan, M. (2010). Marketing to subsistence consumers: Lessons from practice. Journal of Business Research, 63(6), 559-569.

West, J. (2012). Financial literacy education and behaviour unhinged: combating bias and poor product design. International Journal of Consumer Studies, 36(5), 523-530. 